JPPUMA: Jurnal Ilmu Pemerintahan dan Sosial Politik UMA Uournal of Governance and Political Social $U M A$ ), 9 (1) (2021): 1-9, DOI: 10.31289/ippuma.v9i1.3412

JPPUMA: Jurnal Ilmu Pemerintahan dan Sosial Politik UMA

(Journal of Governance and Political Social UMA)

Available online http://ojs.uma.ac.id/index.php/jppuma

\title{
Politics of the Nobility: The Study of Growing Capital Andi in the Mayor`s Election of Palopo 2013-2018
}

\author{
Samsul* \& Zuli Qodir \\ Master of Government Science Study Program, Universitas Muhammadiyah Yogyakarta, \\ Indonesia
}

Submitted: 24 January 2020; Reviewed: 14 May 2020; Accepted: 06 March 2021

\begin{abstract}
The purpose of this research is to find out what causes the weakening of the capital of Andi's nobility in Palopo City in the selection of candidates for mayor and what is the role of Andi's nobility in political contestation. This type of research is descriptive qualitative. The results showed that the capital owned by Andi's aristocracy in Palopo City was. First, the social capital built by Andi's nobility had not been carried out in a structured way from relations with the general public, community leaders, with community organizations, to officials in the bureaucracy and most importantly, Political parties. Second, economic capital is an important thing that used in the Mayor Election contestation in the City of Palopo, Bangsawan Andi figure who escaped as a candidate for mayor does not yet have sufficient capital in terms of funds. Third, the cultural capital owned by Bangsawan Andi, who escaped as a candidate for mayor, still lacked a high bargaining value in political contestation in Palopo City. Fourth, the Symbolic Capital is a capital that sufficiently calculated in the mayor election dispute in Palopo City, namely the title of nobility obtained from the blood of the descendants of the Luwu kings, only it must be accompanied by other capital to elected in political contestation.
\end{abstract}

Keyword: Andi Nobility; Local Politics; Capital.

How to Cite: Samsul, S., \& Qodir, Z., (2020). Politics of the Nobility: The Study of Growing Capital Andi in the Mayor`s Election of Palopo 2013-2018, JPPUMA: Jurnal ilmu pemerintahan dan sosial politik UMA (Journal of Government and political social UMA, 9 (1): 1-9. 


\section{INTRODUCTION}

The flow to recognize the political constellation, which is from the social capital deposits of actors / candidates and individuals in society who have a significant role and influence on the local political process to a comprehensive picture of existing political behavior (Sentika, 2016)

The symbols of ethnic identity found in political communication are, clans as identities, regional languages, accents, and customs. These symbols then gave birth to the stigma of immigrants and natives as a form of differentiation and identification of ethnic identity (Lampe, 2010; Faraidiany et al., 2019; Amin \& Sembiring, 2018; Daulay et.al., 2019; Syofian et.al., 2020). The andi faction contested in the arena of power, namely specifically elections can not be separated from three things, namely the construction of the behavior of the Andi in the structure of society to be the determinant to gain voter sympathy (Tahir \& Razak, 2017). The presence of capital in the andi becomes a tool to contest to be the determinant of victory, habitus and capital.

The social stratification of the BugisMakassar community has given the nobility a privileged position as a strategic elite of other community groups in social structures, and as a top leader in political structures (Najamuddin, 2016; Suharyanto, A., 2014; Maruapey et.al., 2018; Lubis et.al., 2019). The cultural elites in South Sulawesi mostly jumped into the political elite and even controlled the economic base (or at the same time became the economic elite) (Yusuf, 2017). In the current context, the nobleman still plays a patron role by maintaining relationships with his followers (clients)(Muhammad Basir S, 2016) While the educated elite emerged as the second elite when the educated group appeared in the National Movement in South Sulawesi alongside the noble elite (Najamuddin, 2015). The conflict eventually had a lot of influence on the continuation of the revolution in South Sulawesi and throughout its establishment.
This research is very good at analyzing the political interrelationships of local elites and elite conflicts that occurred in the past. The fact that there is a strata group over Bugis society, nobles always have a desire to dominate power and do not hesitate to contest each other between groups. The fact that the Andi factions who are contesting in the arena of power that is specifically elections are inseparable from three things, namely First, building the construction of the behavior of the Andi. Second, the presence of capital in the Andi. Third, habitus and capital(Tahir \& Razak, 2017). Descendants of nobles or kings, consider themselves an "elite" group because they have the highest social strata compared to others. However, this social stratification gradually faded, as did the knighthoods fading (Haris, 2018). The existence of blue blood descendants is decreasing in political contests, one of which is the existence of descendants who have power in their territory (umi kalsum, 2012). Why the nobles in Kedatuan Luwu at this time no longer have much control in the contest held once every five years, that is the question to know. Because the researchers previously only emphasized the principle that the government is still held and won by the elites who titled the Noble especially the title "Andi". The popularity of "Andi" Nobles in Luwu Kedatuan has decreased since 2013 in Palopo City at the end of Drs. H Patedungi Andi Tenriadjeng leadership.

In 2015 in the North Luwu Regency in the history of South Sulawesi, a woman-led as the Head of The Region, namely Indah Putri Indriani's mother paired with Muh. Thahar Rum defeated Arifin Junaidi paired with Andi Abdullah Rahim as incumbent (Purwaningsih, 2015) , , while in East Luwu Regency 2015 was marked by the end of Andi Hatta Marakarma's position as Regent.

In addition, in Luwu Regency itself from a few years earlier in the local elections there was always a nobleman who 
participated in the contest, but in 2018 marked the absence of a nobleman following the local elections in Luwu Regency, previously led by Andi Muzakkar who belongs to the elite kinship group of the noble family Qahhar Muzakkar in Luwu Kedatuan (Purwaningsih, 2015). Since 2018, there is no longer a family of Qakah Muzakkar who served as regional head. Of the four areas in luwu kedatuan, Palopo City as the center of Luwu Kedatuan became one of the focuses of this research.

When we see the track record of the noble Andi itself in the scope of Kedatuan Luwu precisely has such strong power. The above phenomenon provides an overview to know the developments and changes that occurred to the nobles of Andi in Palopo City, namely as the center of Luwu Kedatuan, why andi nobles experienced a decline in popularity in political contests especially in the local elections. Therefore, the author will see What Causes The Weakening of Andi Capital in Kedatuan Luwu In Pilwakot in Palopo City in 20132018 and How Andi Plays Role in Kedatuan Luwu in Mayoral Election in Palopo City in 2013-2018.

\section{RESEARCH METHODE}

This research uses a qualitative descriptive method, conducted in Palopo City. The topic examined was about the weakening of The Noble Andi's capital in political contests. Qualitative research reveals a problem or circumstance or event as it is so that it is revealing facts and gives an objective picture of the true state of the object that is adapted to the problem to be discussed concerning the weakening of the Power of The Nobles andi in political contestation in palopo city may be more using a qualitative approach (moleong, 2005). Several indicators in this study were analyzed using the Nvivo12 Plus software to make it easier to analyze the type of research used, namely qualitative.

\section{RESULT AND DISCUSSION \\ Capital of Andi and Non-Nobles in Palopo Mayoral Election}

Capital is a resource owned by political actors who are then utilized in contesting regional head elections in an arena (field). As an election contestant, a candidate must have a strong combination of modalities to win the contest (Stella Maria Ignasia Pantouw, 2012). The weakening of noble power in Palopo City in this discussion will be analyzed with the capital owned when participating in political contests. There are 4 (four) capitals that will be discussed in this section, namely social capital, economic capital, cultural capital, and symbolic capital.

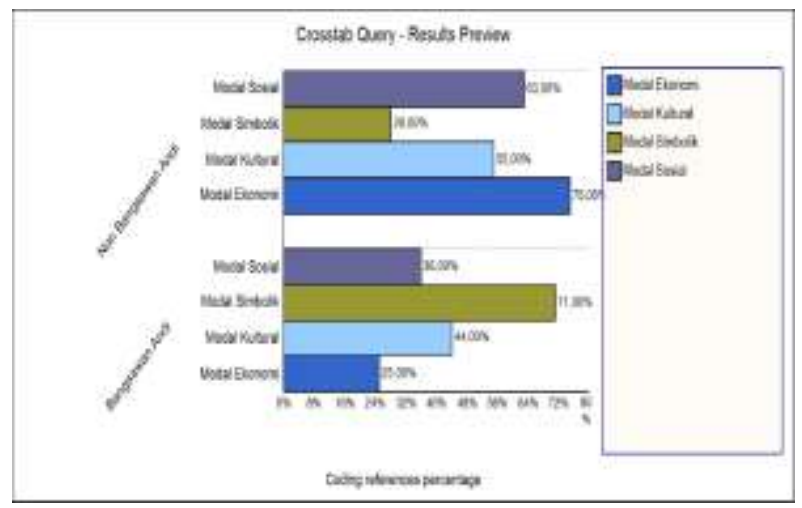

Figure.1. Analysis of capital in mayor election at Palopo City

Source : Data processing of Nvivo, 2020

Data from figure 1, shows that of all the capital of the nobility Andi only superior symbolic capital while the other capital that excels is non-nobles who do not have the title Andi, more specifically we see in the exposure in the division of social, economic, cultural and symbolic capital.

Social Capital. Social capital can be seen in how these actors / elites build relationships with the community without any partition that can certainly be judged by the surrounding people and get a certain award because it can build social relations well. The capital that is needed to become a leader in social capital where the network is often constructed by candidates or political elites into economic capital to help 
them in terms of financing each campaign process and mass mobilization. One of the dominant capitals in political contestation is social capital (Stella Maria Ignasia Pantouw, 2012).

Figure 2, shows that the Social Capital of a nobleman is still lacking in political contestation, in contrast to non-nobles who are superior in terms of social capital. Both in terms of approach with political parties and relations in the bureaucracy. The result of this capital building is in the form of community legitimacy towards political actors that has been felt by the community. Social capital must also be keen to see opportunities especially cooperation with political parties in participating in various political activities because without political parties there is little capital that candidates for mayor in elections are left behind to strengthen support in participating in political contestations such as regional elections, below is a table showing the mayor of 2013 and From the data above shows that the Social Capital of a nobleman is still lacking the path that goes through.

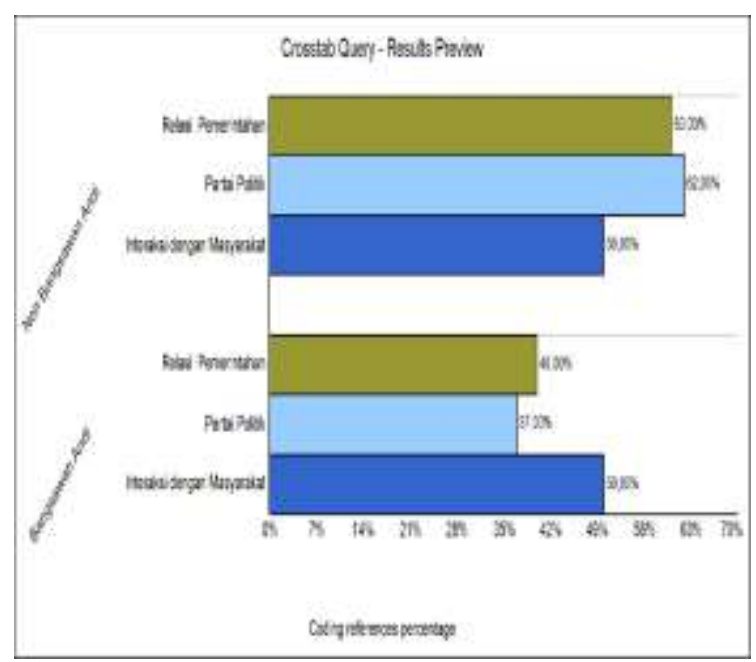

Figure.2. Analysis of social capital Noble Andi dan non-noble in Pilwali Palopo City

Source : Data Processing of Nvivo, 2020

Table.1. Pair of Candidates for Mayor and Vice Mayor Palopo 2013-2018 and Result of Election (First Round)

\begin{tabular}{cllc}
\hline NO & $\begin{array}{l}\text { Name of Pair candidates Mayor and } \\
\text { Vice Mayor }\end{array}$ & Candidates Path & Vote \\
\hline 1 & HM. Judas Amir - Akhmad Syarifuddin & $\begin{array}{l}\text { Political Party : PDP, PNBK, PPDI, } \\
\text { Partai Kedaulatan }\end{array}$ & 19.489 \\
\hline 2 & $\begin{array}{l}\text { A. Akrab Riffai Bassaleng - Pither } \\
\text { Singkali }\end{array}$ & Independen & 2.390 \\
\hline 3 & H. Najamuddin J - H. Waris Karim & Independen & 771 \\
\hline 4 & A. Syaifuddin Kaddiraja - Herman Jaya & Independen & 1.172 \\
\hline 5 & H. Haidir Basir - H. Thamrin Jufri & $\begin{array}{l}\text { Political Party : PPP, PKB, PKPB, PBR, } \\
\text { PKS }\end{array}$ & 19.561 \\
\hline 6 & H. Lanteng Bustami - HM. Yunus & Political Party : PDK, PDIP & 1.448 \\
\hline 7 & H. Rahmat Masri Bandaso - Irwan Hamid & Political party : Partai Golkar & 16.097 \\
\hline 8 & HM. Jaya - Alimuddin Nur & Political Party : PAN, PSI, Hanura & 17.840 \\
\hline 9 & Bustam Titing - Musafir Turu & Independen & 867 \\
\hline
\end{tabular}
Source: KPUD Kota Palopo

From here we can see that the network and social capital owned by andi nobles have not fulfilled in achieving victory in the regional head elections in Palopo City, still using independent channels without the support of any party. In addition, in the second round, there were no more Andi nobles who qualified in the election.
On table.1 Nobleman A. Familiar Riffai Bassaleng before the second round of elections announced KPUD Palopo city has been designated as a suspect of corruption by the KPK, thus making a bad image from the personal side as well as the nobility because previously the former mayor of palopo 2008-2013 namely Drs. H Patedungi Andi Tenriadjeng was also designated as a corruption suspect by the KPK in 2013. 
Until the 2019 elections, Andi's nobility still following the elections as we can see in the remained on an independent path in table below

Table 2. Names of Candidate Mayor for Palopo in 2019-2024

\begin{tabular}{lll}
\hline No & Names of Mayor Candidate & \multicolumn{1}{c}{ Candidates Path } \\
\hline 1 & Judas Amir & PartaiNasdem, Golkar, PKB, Demokrat, PDI-P, PAN, PBB, PPP, dan PKS \\
\hline 2 & Akhmad Syarifuddin Daud & Partai Hanura dan Partai Gerindra \\
\hline $\mathbf{3}$ & Andi khsan Abdul Mutthalib & Independen \\
\hline
\end{tabular}

Source: KPUD Kota Palopo 2018

From the table above is the initial stage of palopo mayoral candidacy 2019 only at this early stage again Andi Ikhsan Abdul Mutthalib was declared not qualified by the Palopo City KPU at the initial selection because it did not meet the requirements. KPUD Palopo City said that Mr. Andi Ikhsan Abdul Mutthalib has not qualified to be a candidate.

The weakening of the power of an Andi nobleman in a political contest is strongly influenced by how they seek political capital that dissects one of them is chatting with political parties. The results of interviews from the youth organizations of the Luwu Raya Student Association (Luwu Regency, Palopo City. North Luwu Regency, and East Luwu) "The last one who had the title of an aristocrat in Kedatuan luwu was Andi Mudzakkar, in 2018 he served as regent of Luwu.

As in the last city of Polopo, Drs. $\mathrm{H}$ Patedungi Andi Tenriadjeng was previously dominated by aristocrats before the formation of Palopo City but in the future, the power of these aristocrats is lacking, one of which is the closeness to political parties so that when they want to nominate they always go through independent channels even though there is an opportunity from another side of the capital. when it is trusted by a political party. We hope at least in the future there is a party that supports so that there is no assumption that the nobles in luwu kedatuan can not build their village". Interview (Jefriadi Junaid, ST. 14 October .2019)

Descendants of Luwu NobleMan, A. Syaifuddin Kaddiraja as a candidate for mayor and also as a customary stakeholder in Luwu kedatuan with the title Opu Maddika Bua. The social capital owned by A. Syaifuddin Kaddiraja is as a stakeholder and historical observer in Kedatuan Luwu.

Economic Capital. Economic capital has important significance as the 'mover' and 'lubricant' of the political machine used. In the campaign season, for example, it takes a considerable amount of money to finance various needs such as printing posters, printing banners, paying for ads, transporting supporters, and various other need.

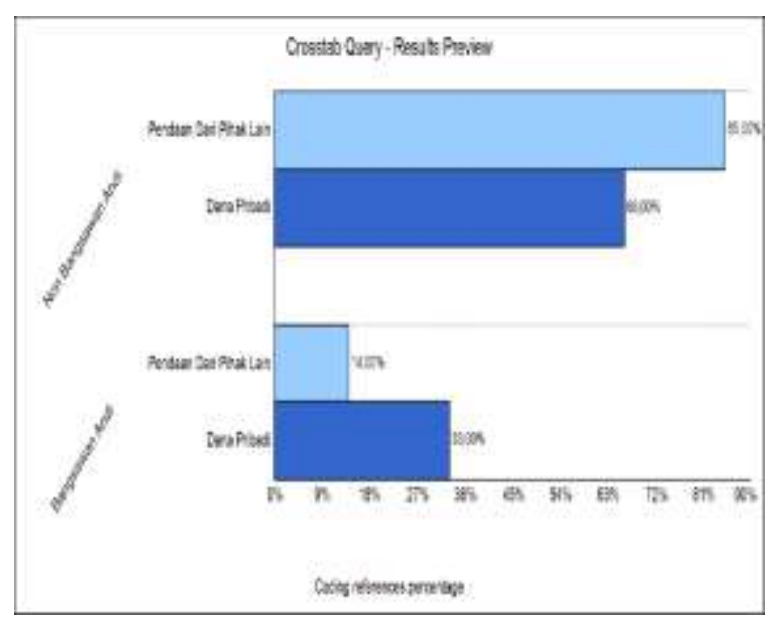

Figure. 3. Analysis of Economy Capital Noble Andi dan non-noble in Pilwali Palopo City Source: data Processing at Nvivo, 2020 
Table 3. The Assets of tah aristocrat and the Mayor Were Selected in The Paolopo Election Year

\begin{tabular}{lll}
\hline \multicolumn{2}{c}{ of 2013} & \\
\hline No & Aristrocrat/Non-Aristocrat & Assets \\
\hline \multirow{2}{*}{1} & A. Akrab Riffai Bassaleng (Bangsawan) & Rp .541.000.000 \\
\cline { 2 - 3 } & A. Syaifuddin Kaddiraja (Bangsawan) & Rp. 652.000.000 \\
\hline 2 & Judas Amir (Walikota Terpiliih/Non Bangsawan) & Rp. 4.526.464.233 \\
\hline
\end{tabular}

Source: Data KPU Kota Palopo, Di Olah Oleh Penulis 2019

From table 3, showing that the economic capital of the nobility andi can not equal the wealth of elected mayors or close, economic capital in terms of wealth is very important to carry out a variety of activities in elections, it's just looking in terms of economic capital has not met when wanting to be paired with the elected mayor because to win a political contest is needed a large fund that is competition. Results of interviews with a traditional speaker from politics and government "Economic capital is very important if we want to participate in political contestation, if we look at the wealth of the aristocrat Andi, during the 2013 election, it was not yet able to fulfill campaign activities and other activities different from that of the mayor. was elected especially since many supporters, including party leaders, then in the 2019 election, Andi Ikhsan has a big chance in terms of wealth, but he did not qualify for the mayor candidate, but in the future, we hope that there will be another nobleman who nominates and can compete with other candidates". (Pua Sumardi Noppo, SE, 29 September, 2019).

Cultural Capital. People of noble or royal descent, consider themselves an "elite" group because they have the highest social strata compared to others.

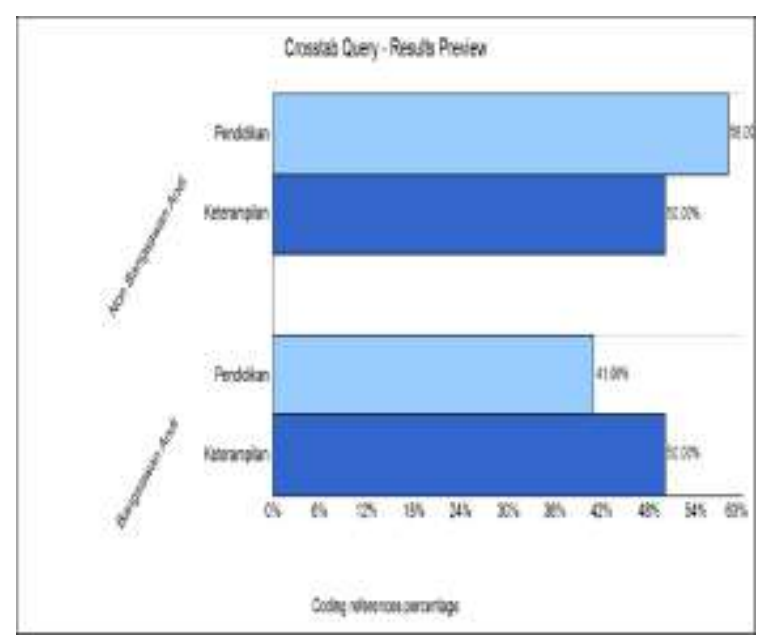

Figure. 4. Analysis of Cultural Capital In Pilwali City Palopo

Souce : data Processing, Nvivo, 2019

Figure 4 , it shows that in terms of education, in cultural capital, the nobility still needs to do a lot of new things in the world of education, while skills have individual abilities. As in terms of literacy, it is clear that the title of nobility is no longer considered as a determinant of a person's social status in the eyes of society. Now education is one of the determining factors in occupying a structural position in the government environment, especially when participating in election competitions. Interview with Macoa Bawalipu "The influence of one's level of education plays a central role in determining their social status. Much different from the past, when the only people who could get an education were those who came from aristocratic descent or people who came from the highest caste, today all people of South Sulawesi without exception have the same rights and obligations as well as the same opportunity as Indonesian citizens to get an education (Bau Muh Aras Abdi To Baji Pua 
Sinri, Bau Muh Aras Abdi To Baji Pua Sinri, 29 September 2019).

Nowadays academic degrees have become a new source of status for the community. People who are not of noble descent are vying to be able to get an education to the highest level, the table below shows the level of education of one of the nobles who participated in the election of palopo mayoral candidate in 2013, because in the 2019 election nobility Andi who qualified as a candidate for Mayor or deputy mayor of Palopo. Education level from high school to strata. The difference in education levels that are seen and juxtaposed with elected mayors, why compared to elected mayors because the benchmark to become a leader is also based on good science.

When looking at the table of aristocrats, Andi does not yet have much power in terms of education, and this is accompanied by a society that is already clever in choosing which one is the best. This is in line with what was said by Muhammad Nur, S.IP, the chairman of the East Luwu Ipmil alumni : "The openness of opportunities and opportunities for everyone to pursue education is increasingly open, which is a qualified economic capability, every society has the same rights regardless of social status.

The opportunity to lead does not require that from among the highest social strata. Currently, it has changed the life order of the people of Palopo City in particular. Social status based on heredity is transferred to the ability of the individual. Whoever he has the ability, then has the right to take a role in society"'. (Muhammad Nur ,S.Ip, 05 Oktober 2019)

Similarly, the Speaker of Adat political and government section about cultural capital is very important in contesting the election of regional heads, the results of the interview as follows: "Education is very important for the provision of knowledge in running the wheels of government, both parties and also the public will be led by figures who have a good quality of education, in addition to the quality of education, the application of public science is also important so that our knowledge is useful to the public. (Interview with Pua Sumardi Noppo, SE. 29 September 2019).

Based on the results of the interview above showed that the cultural capital owned by a candidate for head of the region must be dissected to have a high bargaining value in political contests. Cultural capital is still lacking for a nobleman, especially in the mayoral elections in 2013 and 2019 so that the bargaining value that the community wants in terms of education has not met, as well as palopo mayoral elections in 2019 no more Andi nobles who qualified as candidates, not only cultural capital that influences, but previous capitals are also very influential.

Symbolic Capital. Symbolic Capital is capital that is only owned by descendants of blue blood, in this case, a nobleman can win a political contestation in terms of his descendants. Like the first mayor of Palopo, namely Drs. H Patedungi Andi Tenriadjeng who in 2002-2003 was acting as a temporary task force, after that he was elected as Mayor of Palopo by the DPRD of South Sulawesi in 2003-2008. Not only that, after the direct election, Drs. H Patedungi Andi Tenriadjeng again won the contestation and was re-elected as mayor of Palopo in 2008-2013.

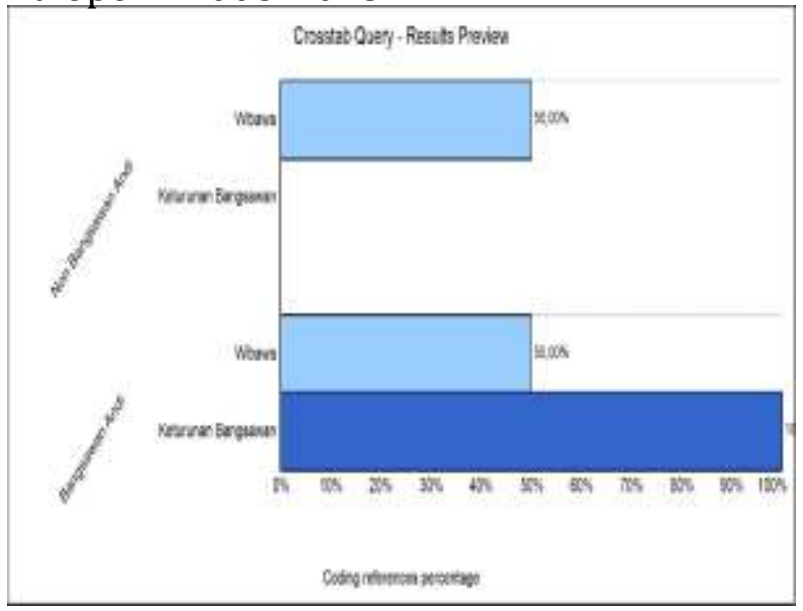

Figure.5. Analysis of Capital Simbolik in Pilwali City Palopo

Source: data Processing, Nvivo, 2020 
Symbolic Capital points to two indicators, namely the descendants of a nobleman and authority, in figure.5. shows that the percentage of an Andi nobleman is high because it does have blue blood ancestry, while in terms of authority has the same percentage.

The symbolic capital that each candidate has is only to provide additional value in the eyes of the public. When viewed in terms of symbolic capital, the descendants of the nobility have a great opportunity to become a leader. It is not enough just to use a symbolic title as a strategy to dominate society in gaining support in the political arena, especially when faced with political rivals who have the same capital, for that it requires the presence of other capitals.

\section{CONCLUSION}

The capital owned by The Noble Andi in Palopo City is the first, the social capital built has not been done in a structured manner ranging from Relations with the General Public, Community Leaders, with community organizations, to officials in the bureaucracy and most importantly the Political Party. Second, economic capital is an important thing used in the contest of Mayor Sorting in Palopo City, the economic capital of Andi Nobles who participated in the election as a candidate for Mayor has not quite competed with other candidates who have a large economic capital. Third, the cultural capital owned by The Noble Andi still does not have enough high bargaining value in political contests in Palopo City. Kurtural capital comes from all educational qualifications possessed by andi nobles, as well as other knowledge. Fourth, symbolic capital is a sufficient capital count in the contest of mayoral elections in Palopo City. Knighthood obtained from the blood of the descendants of the Luwu Kings can provide bargaining value in political contests only symbolic capital gradually in gerus with other capitals such as economic and cultural capital, therefore the weakening of Andi in the palopo mayoral election because of the lack of capital owned in following the political contest,

\section{REFERENCES}

Amin, M., \& Sembiring, W. M. (2018, March). Local election: Does bureaucracy become one of main political power. In IOP Conference Series: Earth and Environmental Science (Vol. 126, pp. 1755-1315).

Basir, S.M., (2016). Bangsawan Dalam Pilkada (Studi Kasus: Pemilihan Kepala Daerah Di Kabupaten Bone).

Dauly, S. M., Kusmanto, H., \& Kadir, A. (2019). Politik Identitas Pada Pemilihan Gubernur Sumatera Utara tahun 2018. Jurnal Administrasi Publik (Public Administration Journal), 9(1), 49-56.

Faraidiany, M, Kusmanto, H. \& Warjio. (2019). Politik Identitas dalam Iklan Politik pada Pemilihan Kepala Daerah Sumatera Utara 2018, JUPIIS: Jurnal Pendidikan Ilmu-ilmu Sosial, 11 (1): 113-120

Haris, R. (2018). Dinamika Kelompok Sosial Budaya Di Kota Makassar: Memudarnya Stratifikasi Sosial Berbasis Keturunan. Jurnal Masyarakat Dan Budaya, 19(2), 189. Lampe, I. (2010). Identitas Etnik Dalam Komunikasi Politik. 15.

Kalsum, U., (2012). Eksistensi Bangsawan Golongan Darah Biru Dalam Pemerintahan Kabupaten Sumenep.

Lubis, A, Nasution, M.A, \& Kusmanto, H. (2019) Peran Kepala Desa dalam Pemilihan Kepala Daerah Kabupaten Deli Serdang Tahun 2018 (Studi pada Desa Bandar Khalipah Kecamatan Percut Sei Tuan Kabupaten Deli Serdang), JPPUMA: Jurnal Ilmu Pemerintahan dan Sosial Politik UMA (Journal of Governance and Political Social UMA), 7 (2): 199-204

Moleong. L.J., (2005). Metode Penelitian Kualitatif.

Maruapey, M.H. Rusli, B. Karlina, N. \& Rahmatunnissa, M. (2018). Implementasi Kebijakan Pemilihan Kepala Pemerintahan Negeri di Kecamatan Salahutu Kabupaten Maluku Tengah. JPPUMA: Jurnal Ilmu Pemerintahan dan Sosial Politik UMA (Journal of Governance and Political UMA), 6 (1): 6875.

Najamuddin. (2015). Persaingan Elit Bangsawan Dengan Kelompok Terdidik Pada Masa Revolusi Di Sulawesi Selatan.

Najamuddin. (2016). Rivalitas Elit Bangsawan Dengan Kelompok Terdidik Pada Masa Revolusi: Analisis Terhadap Pergulatan Nasionalisme Lokal Di Sulawesi Selatan Menuju Nkri.

Purwaningsih, T. (2015). Politik Kekerabatan Dan Kualitas Kandidat Di Sulawesi Selatan. Jurnal 
JPPUMA: Jurnal Ilmu Pemerintahan dan Sosial Politik UMA (Journal of Governance and Political Social UMA), 9 (1) (2021): 1-9

Politik, 1(1), 97-124. Sentika, M. (2016). Program Studi Ilmu Politik Jurusan Ilmu Politik Dan Ilmu Pemerintahan Fakultas Ilmu Sosial Dan Ilmu Politik Universitas Hasanuddin Makassar. 103.

Pantouw, S.M.I., (2012). Modalitas Dalam Kontestasi Politik (Studi Tentang Modalitas Dalam Kemenangan Pasangan Hanny Sondakh Dan Maximiliaan Lomban Pada Pemilukada di Kota Bitung Sulawesi Utara Tahun 2010.

Suharyanto, A., (2014). Partisipasi Politik Masyarakat Tionghoa dalam Pemilihan Kepala Daerah, JPPUMA: Jurnal Ilmu Pemerintahan dan Sosial Politik UMA (Journal of Governance and Political UMA), 2 (2): 166175
Syofian, E., Subhilhar, S., Kusmanto, H., \& Amin, M. (2020). Identity Politics in the 2018 Regional Head Elections for the Governor and Deputy Governor of North Sumatra. Budapest International Research and Critics Institute (BIRCI-Journal): Humanities and Social Sciences, 3(4), 3675-3685.

Tahir, M. M., \& Razak, F. S. H. (2017). Keterlibatan Kaum Bangsawan Dalam Pemilihan Kepala Daerah (Pilkada) Di Kabupaten Pinrang Provinsi Sulawesi Selatan. Public Policy, 5(1), 23.

Yusuf, A. M. (2017). Assituruseng: Hegemoni Budaya Dalam Praktik Politik Dan Kekuasaan Di Belawa. Etnosia: Jurnal Etnografi Indonesia, 2(1), 74. 